\title{
Evaluation of Satellite Image Correction Methods Caused by Differential Terrain Illumination
}

\author{
Purnama Budi Santosa \\ Department of Geodetic Engineering \\ Faculty of Engineering, Gadjah Mada University \\ Corresponding author (email: purnamabs@ugm.ac.id)
}

\begin{abstract}
The problem due to differential terrain illumination on satellite imagery is experienced by most of areas which are on mountainous terrain. This may cause variations in reflectance of similar ground features which lead to a misclassification of land cover classes due to different topographic positions. This phenomenon most commonly occurred in the areas which are located on southern and northern hemisphere because of the low sun inclination. This problem has been a major interest for researchers to be solved prior to the land cover classification process. For satellite images which experience this kind of problem, topographic correction need to be applied in order to reduce the illumination effects prior to land cover classification process. This research is aimed at conducting topographic correction of multi spectral SPOT 5 satellite data as well as evaluating the three topographic correction methods. They are Cosine which is based on Lambertian reflectance assumption, as well as Minnaert correction and C correction methods which are based on non-Lambertian reflectance assumption. The data used in this study are two scenes of SPOT 5 images of forested mountainous area of Miyazaki Prefecture, Kyushu, Japan.Research steps had been conducted in this study including geometric correction, sample data collection for calculating Minnaert constants and $\mathrm{C}$ constants at location which represents the whole study area, topographic correction for two scenes SPOT 5 images, and results analysis. The results show that Cosine method did not show good performance for the study area which is topographically dominated by rugged terrain. Whereas Minnaert method and $\mathrm{C}$ method gave satisfactory results as is indicated by the statistical data as well as visual interpretation. However the Minnaert correction method showed slightly better performance than the $\mathrm{C}$ correction method.
\end{abstract}

Keywords: Minnaert, Cosine, C-Correction, topographic normalization, SPOT, image processing.

\begin{abstract}
Abstrak
Permasalahan yang disebabkan oleh pencahayaan medan permukaan yang berbeda pada citra satelit dialami oleh sebagian besar dari daerah-daerah pada daerah pegunungan. Hal ini dapat menyebabkan variasi dalam pemantulan kenampakan permukaan tanah yang sama yang menyebabkan kesalahan klasifikasi kelas tutupan lahan karena posisi topografi yang berbeda. Fenomena ini paling sering terjadi pada wilayah yang terletak di belahan bumi selatan dan utara karena kemiringan matahari yang rendah. Masalah ini telah menjadi perhatian para peneliti untuk dipecahkan sebelum proses klasifikasi tutupan lahan. Oleh karena itu, untuk citra satelit yang mengalami masalah seperti ini, koreksi topografi perlu diterapkan untuk mengurangi efek pencahayaan sebelum proses klasifikasi tutupan lahan. Penelitian ini bertujuan untuk melakukan koreksi topografi citra satelit multi speltral SPOT 5 serta mengevaluasi tiga metode koreksi topografi. Metode tersebut adalah Cosine yang didasarkan pada asumsi pemantulan Lambertian, serta koreksi Minnaert dan koreksi C yang didasarkan pada asumsi pemantulan nonLambertian. Data yang digunakan dalam penelitian ini adalah dua citra satelit SPOT 5 yang meliputi daerah pegunungan berhutan Prefektur Miyazaki, Kyushu, Jepang. Langkah penelitian telah dilakukan dalam penelitian ini meliputi koreksi geometrik, pengumpulan data sampel untuk menghitung konstanta Minnaert dan konstanta $C$ di lokasi yang mewakili keseluruhan daerah penelitian, koreksi topografi untuk dua citra satelit SPOT 5, dan analisis hasil. Hasil penelitian menunjukkan bahwa metode Cosine tidak menunjukkan kinerja yang baik untuk daerah penelitian yang topografinya didominasi oleh medan permukaan bergelombang. Sedangkan metode Minnaert dan metode C memberikan hasil yang memuaskan seperti yang ditunjukkan oleh data statistik serta interpretasi visual. Namun metode koreksi Minnaert menunjukkan kinerja sedikit lebih baik daripada metode koreksi $C$.
\end{abstract}

Kata Kunci: Minnaert, Cosine, C-Correction, normalisasi topografis, SPOT, pengolahan citra 


\section{Introduction}

For the purpose of monitoring landuse dynamic of the study area from 2004 to 2006 in the Miyazaki Prefecture Japan, detailed information about land cover classes is needed. However, the available data namely multi spectral SPOT 5 satellite data which were acquisitioned in 2004 and 2006 are influenced by topographically induced illumination effects which result in the existence of shadowed areas on the slope that is facing away from the sun. These effects may cause variations in reflectance of similar ground features, leading to a possible misclassification into different land cover classes due to different topographic positions. In order to be able to conduct land cover classification, topographic correction needs to be applied to remove or minimize this error.

For areas which are on flat or gently undulating terrain, where topographically induce illumination effects do not exist significantly, land cover classification from satellite imagery has become a routine practice. However, when the satellite dataset covers areas which are in mountainous terrains, spectral classification is still remain a challenge (Leprieur et al. 1988). For these areas, the classification results often misleading, especially when the topographically induced illumination effects exist. For this case, researchers have attempted to develop methods and techniques to improve the situation, and several strategies have been pursued. The improvements in classification methods and techniques can involve classification algorithm refinement, the use of textural or contextual information derived from the image itself, or the incorporation of ancillary information sources, such as existing maps.

For the case of satellite imageries which experience topographically induced illumination effects, one measure that can be done to improve the land cover classification results is by conducting topographic correction. Several topographic correction methods have been developed and their functionalities have been tested for different satellite imageries on different terrain and land cover conditions (e.g. Twele and Erasmi 2005, McDonald et al. 2002, Meyer et al. 1993, Riano et al, 2003). Twele and Erasmi (2003) tried to evaluate topographic correction algorithms to improve land cover discrimination in tropical forest of mountainous areas based on a Landsat ETM+. The study ended up with the conclusion that the simplistic assumption of Lambertian surface properties was not appropriate for the terrain correction of tropical forest. In contrast, non-Lambertian methods showed good performance in eliminating topographically induced illumination effects. McDonald et al. (2002) evaluated a number of topographic correction algorithms published by Teillet et al. (1982) and Meyer et al. (1993) for Landsat TM data. As part of the land management purposes, this research was aimed at eliminating the shadowing effects exists in the images due to topographic condition coupled with a low sun angle at the time of satellite overpass which the final goal was to improve image classification results. The result came to the suggestion that the most effective illumination correction was C-correction. While the Minnaert correction gave similar results to those of the C-correction, the coefficients for the $\mathrm{C}$-correction were easier to obtain from the data, making its application simpler.

Similar to the previous researches, $\mathrm{Wu}$ et al. (2007) compared different topographic correction algorithms to understand their performance on QuickBird images for undulant area with maximum slope of 7.4 degrees. Among these corrections, the empirical correction proved to be the most effective method for all spectral bands in both the solar and view directions. The cosine correction gave the worst performance, whereas the $\mathrm{C}$ correction and the Minnaert correction performed well for highly non-Lambertian surfaces, but they were less effective than the empirical correction.

The inclusion of constant or coefficient in Minnaert method has become focus of study for 
several researchers. Murakami (2007) studied the derivation of Minnaert constants based on three different forest types. He suggested that there were no significant differences between the derived constants which were calculated from the data extracted from the three forest types with similar topographic conditions. In addition, Minnaert constants derived only from topographic conditions without forest-type specification also presented no significant difference in all bands and all scenes. While not directly confirming that Minnaert constants were similar regardless of forest type, the results suggested that a stable Minnaert constant could be obtained by taking only topographic conditions into consideration. These results contradict with the study conducted by Blesius and Weirich (2005). In this research, they employed Minnaert correction method to improve land cover classification in mountainous terrain. One of the study results suggested that Minnaert constant should be derived from individual land cover classes.

This study investigates three topographic correction methods namely Cosine method which is based on the Lambertian reflectance assumptions, as well as Minnaert and $\mathrm{C}$ method for the non-Lambertian assumption which are proposed by previous researchers as effective and efficient topographic correction method. This is done to compare the results of the three methods on the satellite images which are severely affected by the topographic-induced illumination effects.

\section{Study Area And Data}

The study area is in a mountainous forested terrain of the Hitotsuse area in Miyazaki Prefecture, Kyushu, Japan (Figure 1), bounded within Latitude: $131^{0} 2^{`} 40^{\prime}$ E - 131017 $31^{\prime}$ ” E, and Longitude: $32^{\circ} 10^{\prime} 48^{\prime \prime} \mathrm{N}-32^{\circ} 24{ }^{\prime} 590^{\prime \prime} \mathrm{N}$. The topographic condition is very undulating with maximum slope of about 79.5 degrees, and the elevations ranging from 196 to 1723 $\mathrm{m}$ above sea level. The natural vegetation is warm-temperate evergreen broadleaf forest and secondary natural broadleaf forest presently dominates the area. Other land cover includes coniferous plantation forests composed mainly of Japanese cedar and bamboo forests.

Two SPOT $5 / \mathrm{HRG}$ images were used in this study. The first SPOT satellite data, which is called H18. It was observed in February 3, 2006 at 11:11 am with sun altitude of 37.6175 degrees and sun azimuth 156.4167 degrees. The second satellite data, which is called H16, was observed in October 13, 2004 at 11:07:58 am with sun altitude of 47.9316 degrees and sun azimuth of 160.1751 degrees. The images have four bands: band 1 (visible green, 0.50 $0.59 \mu \mathrm{m}$ ), band 2 (visible red, 0.61-0.68 $\mu$ $\mathrm{m}$ ), band 3 (near-infrared, 0.78-0.89 $\mu \mathrm{m}$ ), and band 4 (SWIR, 1.58-1.75 $\mu \mathrm{m}$ ). The spatial resolution of band 1 to band 3 is $10 \mathrm{~m}$, and band 4 is $20 \mathrm{~m}$.

A 10-m grid digital map created by Hokkaido Map Corporation was used for the digital elevation model (DEM). This DEM was produced based on digital $10 \mathrm{~m}$ contour map at scale 1:25000 published by the Geographical Survey Institute of Japan. This DEM was applied for the geometric registration of satellite data and for the calculation of the solar incidence angle and sensor existence angle in each pixel. The 1:25000 digital map was also used for geometric registration of the SPOT imageries. ERDAS IMAGINE Version 9.1 software (Leica Geosystems Geospatial Imaging, Norcross, GA, USA) was used for preprocessing the satellite data. All data were geometrically registered on a Tokyo Transverse Mercator projection with datum Tokyo. 


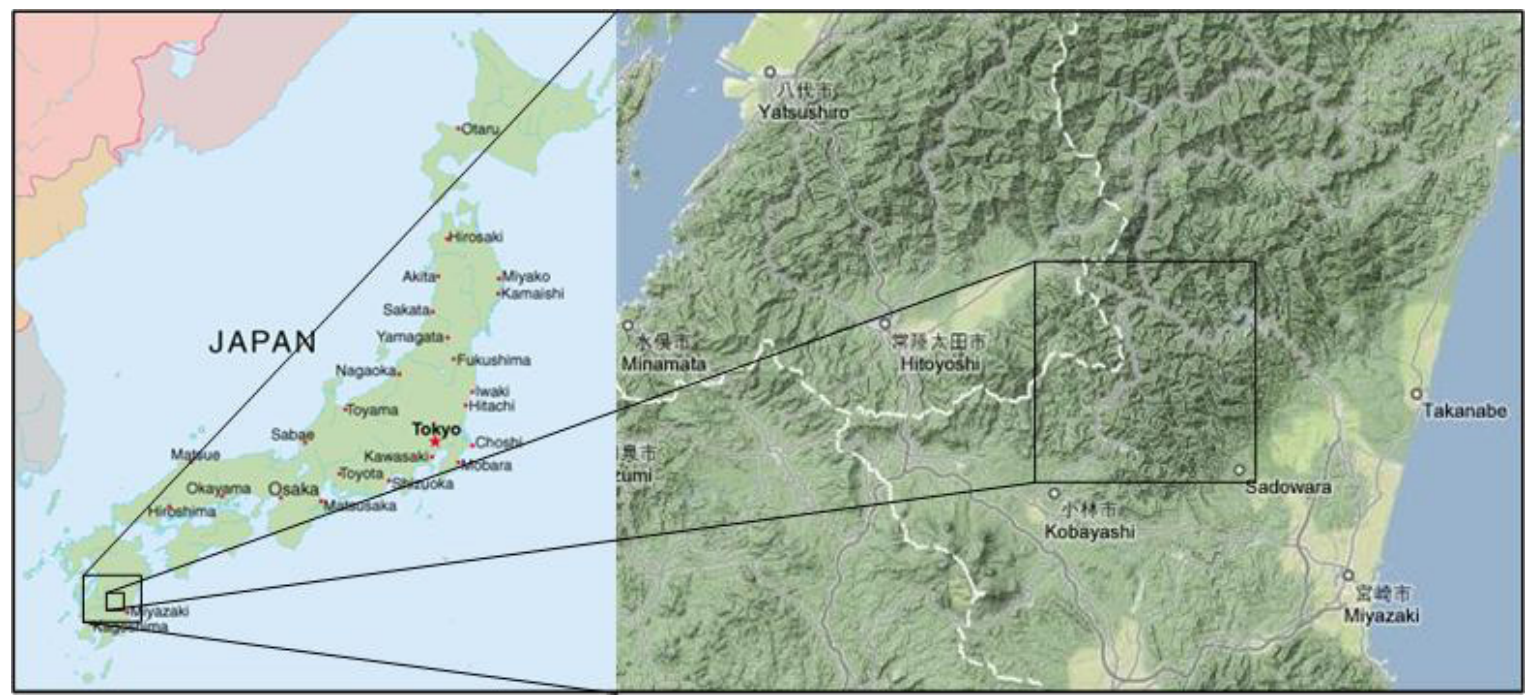

Figure 1. Study location at Hitotsuse area, Miyazaki prefecture, Kyushu, Japan

\section{Methodology}

\section{Data Sampling Method}

The empirical constants which were employed in all non-Lambertian methods i.e. Minnaert and $\mathrm{C}$ method were derived from the sampling areas which were chosen by criteria. The criteria for the sampling area was that the sampling area should represents the whole study areas in terms of topographic condition and vegetation coverage. Therefore, the selection process of the sampling areas could not be done by random sampling. They should be selected based on the terrain condition that may include: vegetation coverage, rough topographic condition and the existence of shadowed and sunny slopes. Over 10000 pixel samples from homogeneous, rugged areas with a broad range of different slope angles and solar aspects were taken.

Once the sampling areas had been selected, these areas would be used for deriving Minnaert constants and $\mathrm{C}$ constants necessary for conducting topographic correction. For the subsequent evaluation of the performance of each correction method, random pixel samplings were chosen including more than 12000 pixel samples in regression analysis. This type of sampling mainly contains pixels of natural forested areas, as well as other types of land cover that contribute to the statistics.

\section{Topographic Correction}

In order to be able to see the topographic effect, the relationship between cosine angle, solar incidence angle and the local surface normal which is modeled in Eq. (1) can be used to achieve this purpose (Civco 1989).

$\cos i=\cos \theta_{0} \cos \theta_{n}+\sin \theta_{0} \sin \theta_{n} \cos \left(\phi_{n}-\phi_{0}\right)$

cosi is the cosine angle between solar incident angle and the local surface normal; $\theta_{0}$ is the solar zenith angle; $\theta_{n}$ is the zenith angle of the normal to the surface; $\phi_{0}$ is the solar azimuth angle; and $\phi_{n}$ is the topographic aspect angle. This relationship can be used to reduce the variance within land-cover classes (Civco 1989). Furthermore, the reflectance property of the surface material is necessarily considered. This is specified by the Bi-directional Reflectance Distribution Function (BRDF), a function defined in terms of incident and exitance angles. According to Woodham and Gray (1987) the BRDF can be analytically inferred, but it cannot be measured. For a Lambertian surface the BRDF is independent of incident angles, or in other words, radiation is reflected in all directions without preference. The Lambertian assumption is formulated as (Woodham and Gray (1987):

$L_{n}=\frac{L}{\cos i}$ 
where $L_{n}$ is normalized radiance and $L$ is measured radiance.

Cosine correction: In this method, the surface is assumed to have Lambertian behaviour, i.e. to be a perfect diffuse reflector, having the same amount of reflectance in all view directions. Thus, the Lambertian correction function attempts to correct only for differences in illumination caused by the orientation of the surface (Jones et al., 1988). For the Lambertian assumption, the most widely used correction is Cosine method using the equation (1), (3) and (4) as follows (Jones et al., 1988):

$L_{n}=L(\lambda) / \cos i$

$L_{H}=L_{T} \cos z / \cos i$

where $L$ is radiance; $Z$ is solar zenith angle; $L_{H}$ is radiance for horizontal surface; $L_{T}$ is radiance observed over the inclined terrain; and $i$ represents incidence angle with respect to surface normal.

Although this correction method is simple and convenient for topographic correction, there is a recognized problem in the corrected images. Thus when correcting the topographic effect under a Lambertian surface assumption, images tended to be over-corrected, with slopes facing away from the sun appearing brighter than sun-facing slopes due to diffuse sunlight being relatively more influential on the shady slope (Jones et al., 1988). Therefore, non-Lambertian topographic correction method has been developed.

C correction: This correction method is based on non-Lambertian assumptions which is to weaken the effect of over-correction in cosine correction when $\mathrm{i}(\mathrm{x}, \mathrm{y})$ approaches $90^{\circ}$. For this purpose, a constant parameter $\left(\mathrm{c}_{\lambda}\right)$ was proposed (Teillet et al., 1982), thus the Eq. (4) becomes (5).
$L_{H}=\left(L_{T} \cos z+c_{\lambda}\right) /\left(\cos i+c_{\lambda}\right)$

$c_{\lambda}=b_{\lambda} / m_{\lambda}$

where $m_{\lambda}$ and $b_{\lambda}$ are the slope and intercept of the regression between $\mathrm{L}_{\mathrm{T}}(\mathrm{x}, \mathrm{y})$ and $\cos (\mathrm{i})$. As Teillet et al. (1982) stated, Eq. (5) could be considered to emulate the effect of diffuse irradiance although the physical analogies are not exact.

Minnaert correction: In a non-Lambertian model, corrections are applied with respect to sun and sensor geometries, and equation (2) becomes:

$L_{n}=\frac{L \cos e}{\cos ^{k} i \cos ^{k} e}$

where $L_{n}$ is the corrected data value, $L$ is the original data value, $i$ is the solar incidence angle, $e$ is the sensor exitance angle, and $k$ is the Minnaert constant. This is reduced to equation (2) if $k=1$, which is the Lambertian assumption. If the sensor is viewing at nadir, the exitance angle is equal to the slope angle. To utilize this relationship, equation (7) needs to be linearized (Jones et al., 1988).

$\log (L \cos e)=\log L_{n}+k \log (\cos i \cos e)$

The Minnaert constant $k$ then represents the slope of the regression line if $\log (L \cos e)$ is plotted against $\log (\cos i \cos e)$, lies between 0 and 1 . It is used to describe the roughness of the surface. When the surface has Lambertian behaviour, the value of the Minnaert constant is 1. Otherwise, it is less than 1. After the Minnaert constant, $k$, is determined, a backwards radiance correction transformation model can be developed (Jones et al., 1988).

$L_{n}=L(\cos e) /\left(\cos ^{k} i \cos ^{k} e\right)$

If we compare this method with the nonLambertian cosine method mathematically, it can be seen that the Minnaert constant, $k$, is used to weaken the power of topographic 
correction. In other words, it is used to describe the roughness of the surface of the terrain. As a result, the problem of overcorrection in the area facing away from the sun can be solved.

\section{Results and Discussion}

\section{Statistical Analysis}

In order to be able to understand the impacts of the correction process towards the original data, statistical data was used to test the accuracy of the correction results. For this purpose, a training area which represents the terrain variations (i.e. covers the sunny and shady slopes of the images) was chosen. Linear regression method was used to compare the results of the pre-corrected and post-corrected data and for each subsequent illumination corrections. Figure 2 shows an example of the relationship between H16 SPOT Band 2 digital number (DN) and incidence angle for both uncorrected and corrected data at a training area.

Figure 2 (a) shows the behavior of the digital number of H16 SPOT Band 2 towards the incidence angle. It shows positive linear relationship between the $\mathrm{DN}$ and the incidence angle. The linear regression equation parameter is shown in Table 1 . The equation gives $m$ slope of 16.843 and $b$ intercept of 34.074 with coefficient of determination of 0.192 . Figure 2 (b) shows the effect of applying a C-Correction on the same dataset. The relationship between $\mathrm{DN}$ and the incidence angle is reduced from the dataset. As can be seen from Table 1, the equation for the trend line gives a $m$ slope of -3.482 and $b$ intercept of 50.115 with coefficient of determination of 0.049 . As the purpose of applying an illumination correction is to reduce the effect of the incidence angle on the image digital number, Figure 2 (b) shows the success of the C-Correction as is indicated by the decreasing value of coefficient of determinant from 0.192 to 0.049 .

(a) H16 SPOT Band 2: Uncorrected

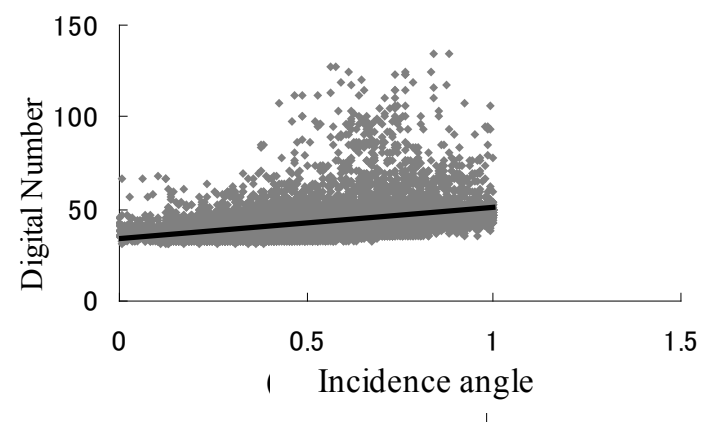

(b) H16 SPOT Band 2: C-Correction

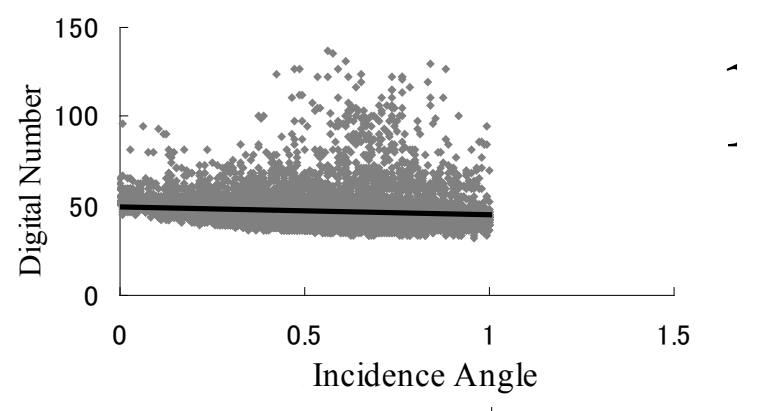

Figure 2. Linear regression of illumination versus band 2 for uncorrected data (a), and C-corrected data (b)

In order to clarify the effect of each topographic normalization method for all bands, the statistical data was presented in table 1. It shows the summary of statistical data of the pre-corrected and post corrected dataset for H16 dataset. The performance of each correction method can be interpreted form this data. The decreasing values of slope $m$, coefficient of determination, and standard deviation of the corrected dataset when compared with the uncorrected dataset indicates the level of success of the correction. In addition, the success of the correction can also be seen from the decreasing range values between minimum DN and maximum DN. 
Table 1. Summary of statistical data of the uncorrected and corrected H16 data.

\begin{tabular}{clccccccc}
\hline H 16 & $\begin{array}{l}\text { Correction } \\
\text { name }\end{array}$ & $\begin{array}{c}\text { Slope } \\
\mathbf{m}\end{array}$ & $\begin{array}{c}\text { Intercept } \\
\mathbf{b}\end{array}$ & $\begin{array}{c}\text { Coeff. } \\
\text { Of det. }\end{array}$ & $\begin{array}{c}\text { DN } \\
\text { Min }\end{array}$ & $\begin{array}{c}\text { DN } \\
\text { Max }\end{array}$ & $\begin{array}{c}\text { DN } \\
\text { Mean }\end{array}$ & $\begin{array}{c}\text { Std. } \\
\text { Dev. }\end{array}$ \\
\hline \multirow{2}{*}{ Band 1 } & Uncorrected & 65.225 & 31.710 & 0.487 & 19 & 140 & 70.330 & 23.100 \\
& Cosine & -12.076 & 87.011 & 0.024 & 26 & 104 & 79.388 & 15.306 \\
& Minnaert & 3.155 & 77.133 & 0.011 & 36 & 106 & 81.095 & 15.261 \\
& C-Corection & -5.702 & 86.672 & 0.019 & 28 & 107 & 80.309 & 15.973 \\
& & & & & & & & \\
Band 2 2 & Cosine & -72.732 & 101.420 & 0.674 & 27 & 102 & 59.135 & 17.505 \\
& Minnaert & -2.112 & 45.878 & 0.019 & 26 & 108 & 43.225 & 8.559 \\
& C-Corection & -3.482 & 50.115 & 0.049 & 32 & 86 & 46.727 & 6.728 \\
& & & & & & & & \\
& Uncorrected & 12.080 & 41.251 & 0.297 & 38 & 167 & 49.868 & 6.396 \\
Band 3 3 & Cosine & -93.618 & 122.040 & 0.786 & 32 & 122 & 67.485 & 21.245 \\
& Minnaert & -4.444 & 52.324 & 0.118 & 29 & 104 & 47.394 & 6.329 \\
& C-Corection & -4.555 & 56.838 & 0.179 & 38 & 93 & 51.833 & 5.199 \\
& & & & & & & \\
Band 4 4 & Cosine & -57.699 & 113.900 & 0.235 & 30 & 143 & 81.196 & 24.711 \\
& Minnaert & -5.581 & 81.614 & 0.016 & 33 & 116 & 75.382 & 17.985 \\
& C-Corection & -7.046 & 91.194 & 0.101 & 31 & 120 & 75.086 & 19.779 \\
\hline
\end{tabular}

From the slope $m$ and coefficient of determination values in table 1 , it can be seen that Minnaert method gives the best results as is indicated by the lowest values of those parameters for all bands, regardless the fact that the standard deviation values for band 2 and 3 are not the lowest. In contrary, the Cosine method gives the worst results due to overcorrection as is indicated by large increase of slope for band 2, 3 and 4 from 16.843, 12.080 and 51.206 to $-72.732,-93.618$ and -57.699 respectively.

Figure 3 shows the relationship between precorrected image, post-corrected image and illumination. The figure reveals the effect of too large Minnaert constants towards the H16 image Band 1 under existing illumination intensity. When the illumination (Cos-i) decreases, the DN of the pre-corrected dataset at the respective areas also decreases. The effect of inappropriate Minnaert correction (which is supplied by too large Minnaert constants) can be seen from the dramatic increase of the pixel DN at the respective locations. At those locations, the uncorrected dataset with pixel $\mathrm{DN}$ at around 50 to 90 change dramatically after correction as can be seen from its dramatic increasing values at maximum of 256 . This phenomenon indicates the existence or overcorrection. This happens in areas where the incidence angle approaches 90 degrees (that is, where cosi tends towards zero) the fraction becomes very large and when multiplied by the pixel DN it creates a disproportionate brightening effect. The suitable Minnaert constant for Minnaert correction as well as $\mathrm{C}$ constant for $\mathrm{C}$ correction should be able to eliminate these dramatic changes of the pixel $\mathrm{DN}$ at low illumination intensity. However these suitable constants often difficult to find. The derivation of Minnaert or $\mathrm{C}$ constants from the sampling area often did not satisfy the purpose. Therefore, appropriate sampling selection should be done carefully. 


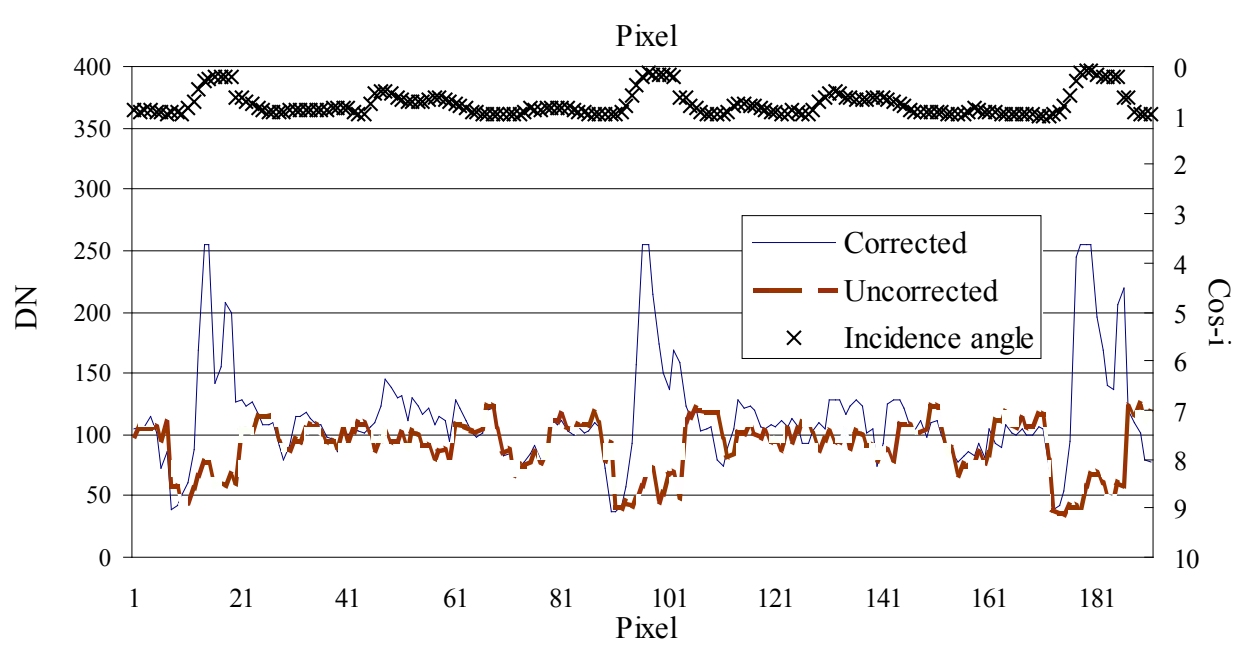

Figure 3. The behavior of H16 image Band 1 towards illumination for Minnaert correction.

\section{Visual Analysis}

Another effective way of evaluating the correction results is by investigating the corrected images visually. By visual interpretation, the effect of the correction can be clearly seen. One key visual interpretation to see the effectiveness of the correction is by comparing individual band between uncorrected and corrected images. An indication of the success of the correction is when the resulting band shows the similar grey level between the shadowed areas and the sunny areas. Figure 4 (a) and figure 4 (b) show visual interpretation of the uncorrected and Minnaert corrected Band 2 of H16. The shadowed areas in the uncorrected image (figure 4 (a)) which is represented by dark color, looks brighter in the Minnaert corrected image (figure 4 (b)), result in similar grey level between the shadowed and sunny areas. A comparison between the original band 2 and the Minnaert corrected band 2 shows a reduction of the relief effects. This leads to a lost of the three-dimensional impression of the corrected image caused by the illumination. As can be seen from the table 1, the Minnaert correction caused the decreases of linear regression slope $m$ and coefficient of determination of uncorrected band from
16.843 and 0.192 to -2.112 and 0.019 in corrected band respectively. The corrected image looks flatter than the uncorrected one and more or less homogeneous in regions of identical objects. The appearance of forests, for instance, becomes much more independent from topography than in the original (uncorrected) bands.

As visual effect is more impressive in true color composite than the single band, the true color composite of band 213 is carried out. Figure 5 presents this visual interpretation of original image, Cosine corrected, Minnaert corrected, and C corrected for H16 and H18 respectively. The result visualization was done by applying the same histogram stretch so that a visual comparison of the pre-corrected versus post-corrected data could be made. The images in figure 5 are represented by Bands 1 , 2 and 3 for green, red and blue respectively. The choice of this band combination is based on the statistical data results summary (table 1) that shows good improvement on these bands, especially for Minnaert correction and $\mathrm{C}$ correction methods; as well as the more natural look resulted from this band combination especially for vegetated areas which is represented by green dominant color. 


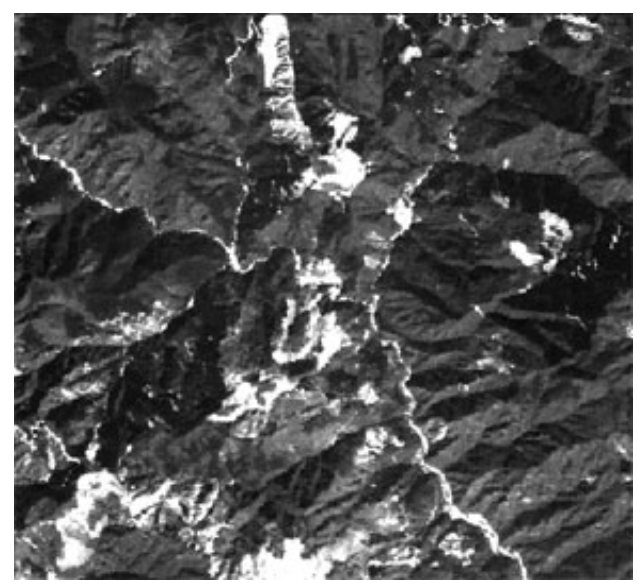

(a) H16 Band 2 image: Uncorrected

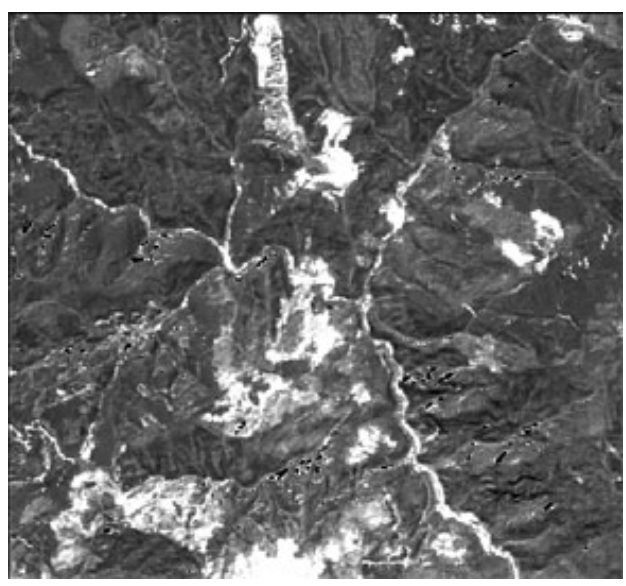

(b) H16 Band 2 image: Minnaert Corrected

Figure 4. Comparison of uncorrected and Minnaert corrected Band 2.

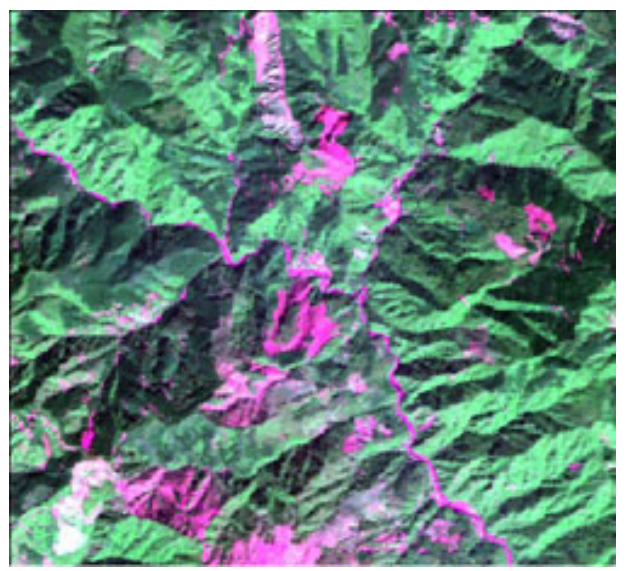

(a) H16: Original image

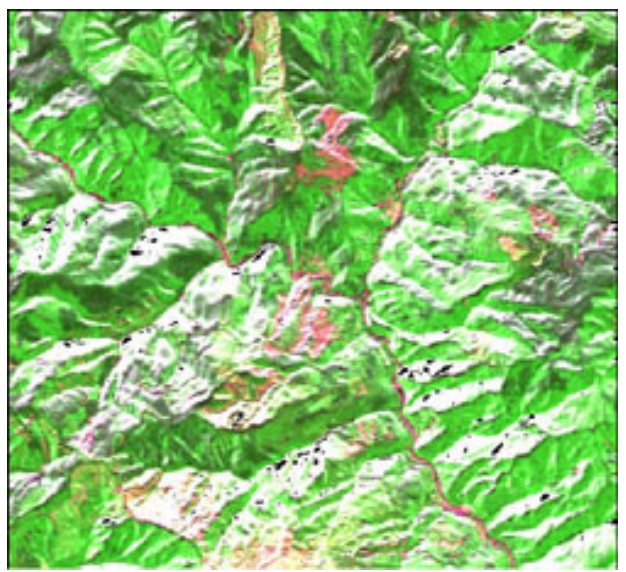

(c) H16: Cosine correction

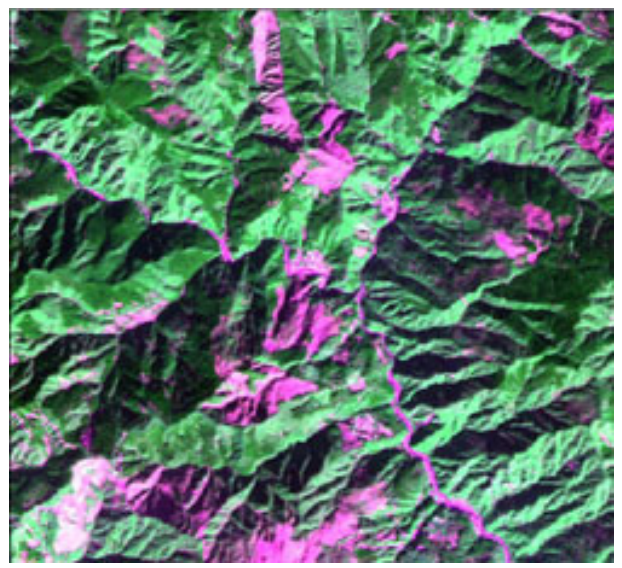

(b) H18: Original image

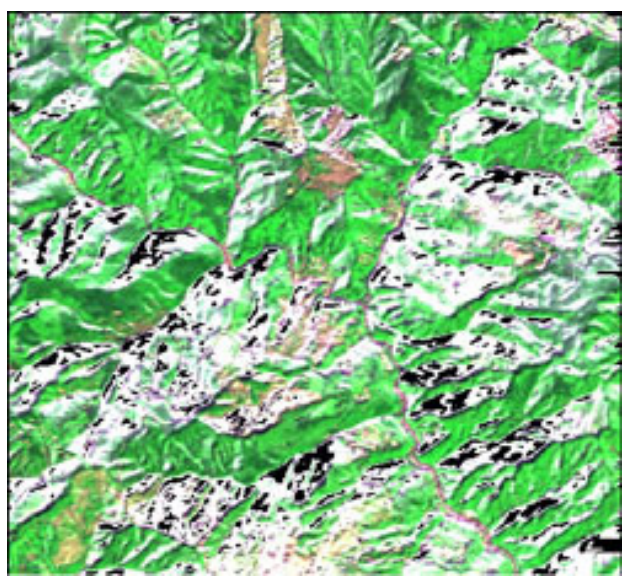

(d) H18: Cosine correction

Figure 5. Image visualization of original and corrected images. 


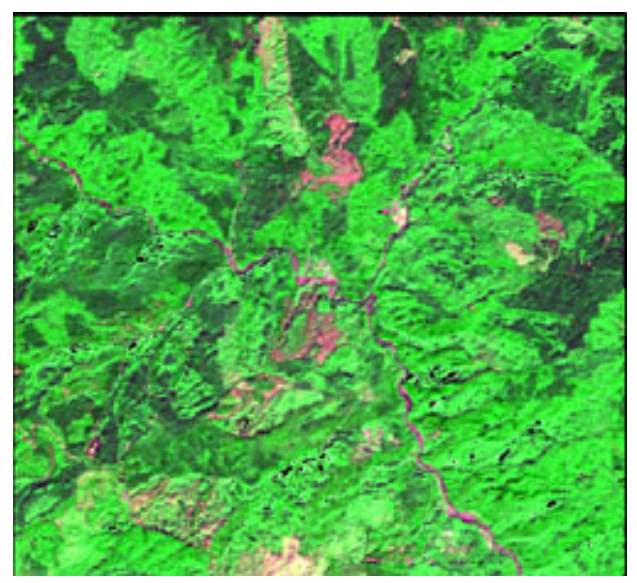

(e) H16: Minnaert Correction

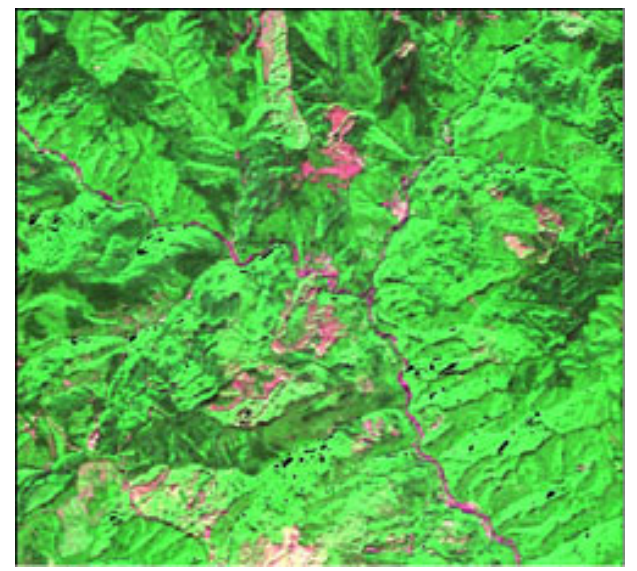

(g) H16: C Correction

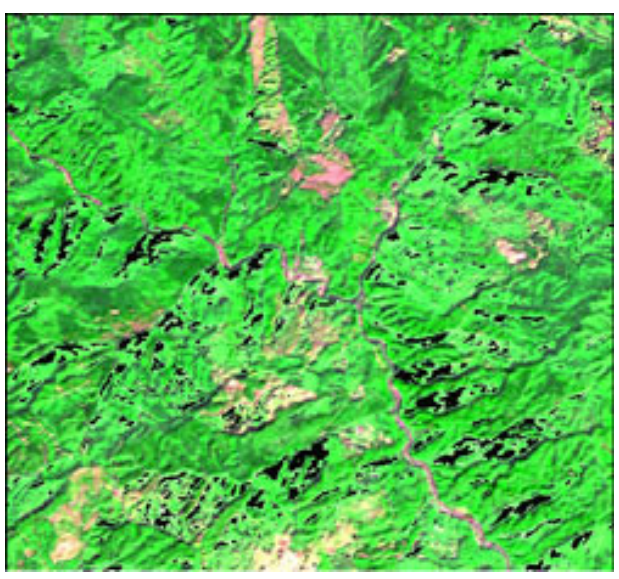

(f) H18: Minnaert Correction

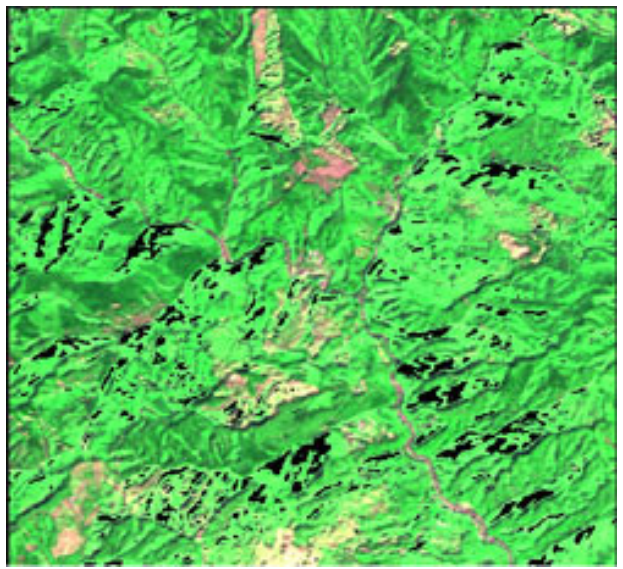

(h) H18: C Correction

Figure 5. (continued)

From Figure 5, by comparing the images visually, it can be seen that all of the images show a decrease in illumination effects when the correction was applied, except in the case of the Cosine. Figure 5(c) and figure 5 (d) which are Cosine corrected H16 and Cosine corrected H18 respectively, show the problem of overcorrection on the shadowed areas throughout the images. The corrected image appears to be too bright especially in the sunshaded slopes. Significant improvement of the correction can be seen in figure 5(e) and figure 5(f). We can see from these figures that the visual effect on the slope facing away from the sun has been improving significantly as a result of Minnaert correction method. Both the slope facing to the sun and slope facing away from the sun with same cover type appear to have similar brightness. In comparison, the quality of the Minnaert corrected and C-corrected images for both $\mathrm{H} 16$ and $\mathrm{H} 18$ are visually similar. However, Minnaert corrected images gives slightly better results as is indicated from statistical data summary in table 1, as well as from visual interpretation. From the visual interpretation, Minnaert correction method gave more natural impression of the surface texture than the $\mathrm{C}$ correction method.

One interesting fact that can be seen from the figure 5 is the occurrence of cast shadow areas, as is indicated by the black areas in the images. These areas have pixel DN of zero. The cast shadow areas in the H18 are much bigger than that of $\mathrm{H} 16$ due to different sun altitude and sun azimuth during the SPOT data acquisition. The H18 was acquisitioned with sun altitude of 37.6175 degrees, significantly lower than the $\mathrm{H} 16$ with sun altitude of 47.9316 degrees, at relatively similar sun azimuth. For the cast shadows areas, for pixels in complete self shadow (i.e. $\cos -i=0)$ ), a division by 0 
occurs, leading to the creation of artifacts in the data (Meyer, 1993). By employing Minnaert constant and $\mathrm{C}$ constant in Minnaert method and C-method respectively, has significantly reduced the large amount of overcorrection which exists in Cosine method. However it should be noted that the problem of cast-shadow, where the incident angle $i>$ 90 degrees, is not handled in this correction method and remains to be uncorrected. Castshadows are not handled with any correction methods and appear dark. A special treatment of these pixels would be necessary.

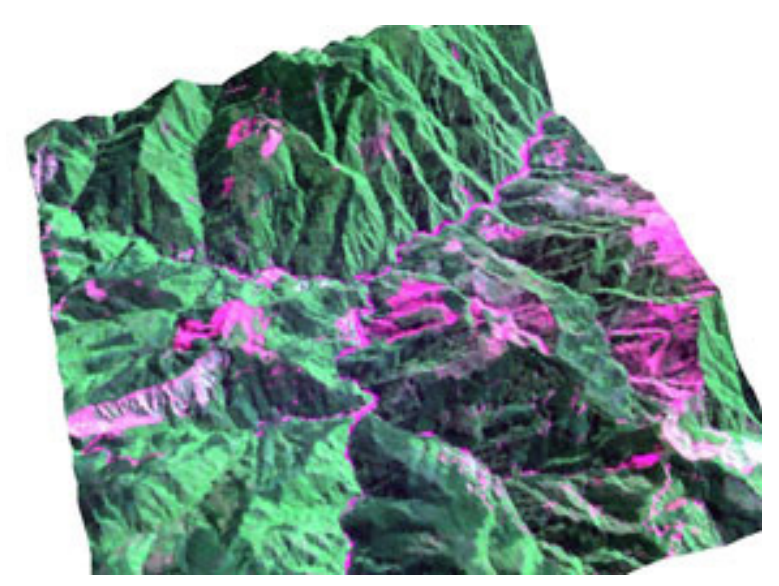

(a) 3D view of uncorrected H16 image
To better visualize the effect of the correction, $3 \mathrm{D}$ visualization of both uncorrected and C-corrected is presented in figure 6. In figure 6 (a), the shadowed slope can be seen clearly throughout the area. These shadowing artifacts give three dimensional impressions that represent terrain condition throughout the study area. However, by applying C-correction, those areas are represented with similar spectral values. This leads to the disappearance of the three dimensional impression of the corrected image, as seen in figure $6(b)$.

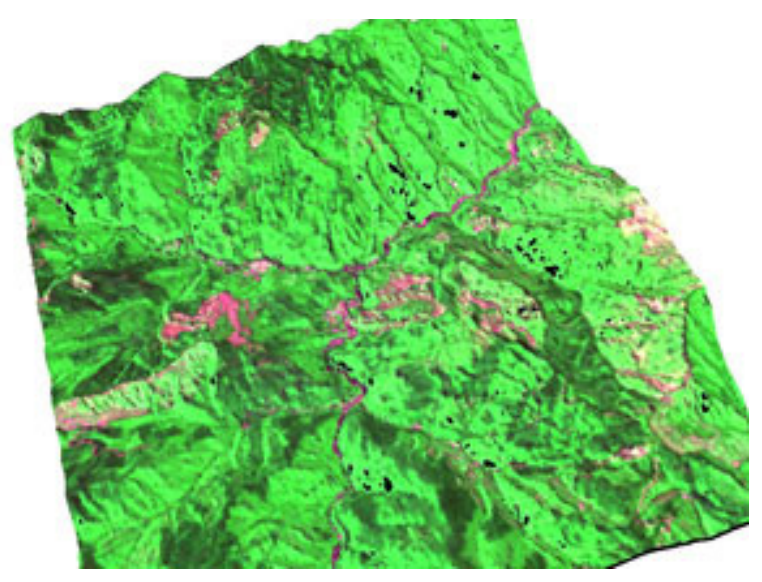

(b) 3D view of C-corrected H16 image

Figure 6. 3D visualization of uncorrected and corrected h16 image by C-Correction method.

The more effective use of Minnaert method and $\mathrm{C}$-method than Cosine method in conducting topographic correction for this image has been predicted earlier. Cosine method is based on the Lambertian reflectance model that assumes the surface reflects incident solar energy uniformly in all directions, and that variations in reflectance are due to the amount of incident radiation. This Lambertian assumption is not valid for the study area since its topography is dominated by rough terrains. On the other hand, the non-Lambertian assumptions seems to be suitable for this conditions since the study area is dominated by forested areas and very undulant terrain conditions, as is demonstrated by Minnaert correction and $\mathrm{C}$ correction methods.

\section{Conclusion}

Three topographic correction methods have been tested on two SPOT 5/HRG images of H16 and H18, namely Cosine correction method, Minnaert correction method and $\mathrm{C}$ correction method. These three topographic correction methods had different degrees of effectiveness in reducing the dependence of image DN values on the illumination geometry. Based on the experiments, the Cosine method does not perform well for the given satellite images. The Lambertian assumption which is presumed by this correction method was not appropriate for the study area which was dominated by rugged terrain throughout the study area. This correction result in overcorrection which was represented by dramatic change of the DN of corrected dataset at the shadowed areas. 
Based on the statistical data and visual interpretation, Minnaert correction method gave the best results. This method performed well for highly non-Lambertian surfaces, as well as C-correction method which showed good performance even though not as good as the Minnaert method. The inclusion of constants in Minnaert correction method and C correction method has successfully reduced the effect of overcorrection which experienced by the Cosine correction method.
Since the ultimate goal of the topographic correction is to improve the land cover classification, the evaluation of the effectiveness of the topographic corrections for the land cover classification results will be conducted in the next research. Furthermore, the cast shadows which occur during the topographic correction also need to be considered in order to be able to achieve better land cover classification results.

\section{References}

Blesius, L. and Weirich, F. (2005). The use of the Minnaert correction for land-cover classification in mountainous terrain. International Journal of Remote Sensing, vo. 26, No. 17, 10 September 2005, 3831-3851.

Civco, D. L. (1989). Topographic normalization of Landsat Thematic Mapper digital imagery. Photogrammetric Engineering and Remote Sensing, 55, pp. 1303-1309.

Giles, P. T. (2001). Remote sensing and cast shadows in mountainous terrain. Photogrammetric Engineering \& Remote Sensing, vol. 57, no. 7, July 2001, pp. 833-839.

Jansa, J. (1998). A global topographic normalization algorithm for satellite images. International Archives of Photogrammetry and Remote Sensing. Vol XXXII, Part 7, Budapest, 1998.

Jones, A. R., Settle, J. J. and Wyatt, B. K. (1988). Use of digital terrain data in the interpretation of SPOT-1 HRV multispectral imagery. International Journal of Remote Sensing, 9, pp. 669-682.

Leprieur, C. E., Durand, J. M. and Peyron, J. L. (1988). Influence of topography on forest reflectance using Landsat Thematic Mapper and digital terrain data. Photogrammetric Engineering and Remote Sensing, 54, pp. 491-496.

McDonald, E. R., Wu, X., Caccetta, P. and Campbell, N. (2002). Illumination correction of Landsat TM data in South East NSW. Environment Australia. Retrieved on February 5, 2008 from: http://www.environment.gov.au/land/publications/illumination/index.html

Meyer, P., Itten, K., Kellenberger, T., Sandmeier, S. and Sandmeier, R. (1993). Radiometric corrections of topographically induced effects on Landsat TM data in an alpine environment. ISPRS Journal of Photogrammetry and Remote Sensing, 48(4):17-28.

Murakami, T. (2007). Comparison of Minnaert constants based on multi-temporal SPOT/HRV data for three forest types. Bulletin Faculty of Agriculture, Niigata University, 60:83-90, 2007.

Riano, D., Chuvieco, E., Salas, J. and Aguado, I. (2003). Assessment of different topographic corrections in Landsat-TM data for mapping vegetation types. IEEE Transactions on Geoscience and Remote Sensing, vol. 41, No. 5, May 2003.

Teillet, P. M., Guindon, B. and Goodenough, D. G. (1982). On the slope-aspect correction of multispectral scanner data. Canadian Journal of Remote Sensing, 8, pp. 84-106.

Twele, A. and Erasmi, S. (2005). Evaluating topographic correction algorithms for improved land cover discrimination in mountainous areas of central Sulawesi. In Remote Sensing 
\& GIS for Environmental Studies (Gottinger Geographische Abhandlungen) edited by Stefan Erasmi, Bernd Cyffka and Martin Kappas, vol. 113, Gottingen, 2005.

Woodham, R. J. and Gray, M. H. (1987). An analytic method for radiometric correction of satellite multispectral scanner data. IEEE Transactions on Geoscience and Remote Sensing, GE-25, pp. 258-271.

Wu, J., Bauer, M. E., Wang, D. and Manson, S. M. (2007). A comparison of illumination geometrybased methods for topographic correction of QuickBird images of an undulant area. ISPRS Journal of Photogrammetry \& Remote Sensing. doi:10.1016/j.isprsjprs.2007.08.004. 